\title{
AEROSPACE APPLICATIONS OF BATTERIES
}

\author{
Shahid Habib \\ NASA Headquarters \\ Washington, DC
}

\section{ABSTRACT}

NASA has developed battery technology to meet the demanding requirements for aerospace applications; specifically, the space vacuum, launch loads, and high duty cycles. Because of unique requirements and operating environments associated with space applications, NASA has written its own standards and specifications for batteries.

\section{INTRODUCTION}

Since 1958 , over 300 NASA spacecraft have used primary or secondary batteries. Primary batteries provide energy to critical systems on launch vehicles and portable equipment used by humans in space. Secondary battery systems supply power, usually $28 \mathrm{~V} \mathrm{DC}$, when spacecraft are in darkness. When a spacecraft is in sunlight, photovoltaic cells power the satellite and darkness. When a spacecraft is in sunlight, photovoltaic cells power the satellite and charge the secondary battery.

The orbit determines the duty cycle for a secondary battery. Low Earth orbit applications are the most demanding because the spacecraft passes through the Earth's shadow on almost every orbit. Since a typical orbit period is $95 \mathrm{~min}$, the battery must be recharged rapidly. Satellites in higher orbits need batteries less frequently--these orbits have longer periods and are more often totally in sunlight. A typical spacecraft has a design lifetime of three years. (Table 1)

NASA has used nickel-cadmium batteries for over 160 satellites to low Earth orbit, geostationary orbit, and the nearby planets. Some recent NASA applications are Topex/Poseidon, the Tracking and Data Relay Satellite, and Mars Observer. The Hubble Space Telescope uses nickel-hydrogen batteries, and the Extravehicular Mobility Unit used on Shuttle missions has a silver-zinc primary battery. Descriptions of these applications follow. NASA also uses many other battery chemistries.

\section{TOPEX/POSEIDON SPACECRAFT}

To increase our understanding of global ocean circulation, the Topex/Poseidon spacecraft (Figure 1) carries two radar altimeters for making very precise measurements of sea level. The French space agency, Centre National d'Etudes Spatiales (CNES), and NASA built the altimeters. The designs permit correction of measurement errors induced by the atmosphere and ionosphere. Uncertainty in the orbital position limits the accuracy to about $14 \mathrm{~cm}$, even though the satellite is at a high altitude for low drag and uses both laser and microwave Doppler tracking methods. On August 10, 1992, an Ariane rocket launched Topex/Poseidon from Kourou, French Guiana into a 66 degree inclination orbit.

Topex/Poseidon uses NASA's Multimission Modular Spacecraft (MMS), a design first used in 1980 for the Solar Maximum Mission. Because the Instrument Module always faces the Earth, the single panel of solar cells that provides at least $2260 \mathrm{~W}$ of power has gimbals to track the 
sun. The Modular Power System (MPS) contains the power conditioning electronics and three batteries with 22 NASA 50 Ah Ni-Cd cells (Figure 2). Topex/Poseidon is the sixth mission to use this battery; the first was Landsat 4 in 1982. NASA initiated the design effort for this battery in 1975. From a total production of over 1400 cells, industry has made 23 flight batteries plus 20 test or spare units. References 1 and 2 define the design. The only qualified cell supplier is Gates Aerospace Batteries.

\section{TRACKING AND DATA RELAY SATELLITE}

From its geostationary orbit the Tracking and Data Relay Satellite (TDRS) links NASA controllers on the ground with satellites in low Earth orbits (Figure 3). For example, TDRS provides voice, television, and data communications to and from the Space Shuttle. Two TDRS satellites are stationed over the Atlantic and the other two over the Pacific. Except for a small zone over the Indian Ocean, TDRS allows continuous communications between a satellite and the ground. A ground station at White Sands, New Mexico controls all four satellites. TDRS receives high rate data at up to $300 \mathrm{Mbps}$ through two large K-band antennas dedicated to (pointed at) specific satellites. There is also a low rate S-band service that can be shared by up to 20 user satellites.

Each TDRS satellite has two solar arrays supplying $1700 \mathrm{~W}$ while tracking the sun. Three $\mathrm{Ni}$-Cd batteries can supply $1400 \mathrm{~W}$ while TDRS is in darkness for a $1.3 \mathrm{hr}$ period per day. The batteries are reconditioned by completely discharging the cells just before the two 45-day periods per year when they are needed.

\section{MARS OBSERVER}

Mars Observer began its trip to Mars in October 1992 and will arrive in August 1993 (Figure 4). After a four month period for checkout and orbit adjustments, the spacecraft will map the surface and profile the atmosphere using a complementary instrument set covering spectral regions from radio waves through gamma rays. The mapping phase will continue for at least a full Mars year or 22 months. The 117 minute mapping orbit is nearly circular and polar. Darkness periods vary seasonally between 36 and 42 minutes.

The solar array power is $1130 \mathrm{~W}$ when initially deployed and $930 \mathrm{~W}$ when fully deployed at Mars. The batteries provide approximately $500 \mathrm{~W}$ for the spacecraft during launch, maneuvers, orbit insertion, and occultations. There are two $42 \mathrm{Ah} \mathrm{Ni}-\mathrm{Cd}$ batteries; the cells are similar to the NASA 50 Ah cell. Because there are only 17 cells per battery, an electronic circuit produces the

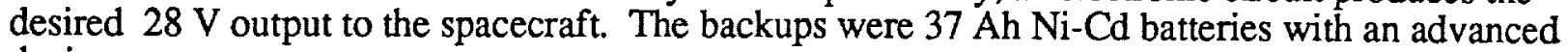
design.

\section{HUBBLE SPACE TELESCOPE}

The Hubble Space Telescope (HST) (Figure 5), launched three years ago, makes observations at ultraviolet wavelengths and with higher angular resolution than any telescope that must look through the Earth's atmosphere. HST's major accomplishments include observations of the early stages of star formation, and the development of a major storm in Saturn's atmosphere. HST has a very accurate attitude control system that points the telescope toward a star, galaxy, or planet while the articulated solar arrays follow the sun. After a Shuttle servicing mission in 
December 1993, HST will be more productive and reliable with its new solar arrays and gyroscopes, a new Wide Field and Planetary Camera with corrective optics for improved resolution, and separate corrective optics for the other instruments.

To meet a 15-year lifetime requirement, the original HST design had Ni-Cd batteries in units that could be replaced on orbit. Given problems with $\mathrm{Ni}-\mathrm{Cd}$ batteries and a 4-year launch delay for other reasons, NASA decided to substitute $\mathrm{Ni}^{-\mathrm{H}_{2}}$ batteries (Figure 6). Each of HST's 6 parallel batteries has 22 cylindrical cells. Actual capacity is 75 to $80 \mathrm{Ah}$ per battery, and in normal operation the depth of discharge is less than 10 percent. NASA plans to use $\mathrm{Ni}-\mathrm{H}_{2}$ batteries on other large spacecraft.

\section{EXTRAVEHICULAR MOBILITY UNTT}

Astronauts performing space walks wear a special suit known as an Extravehicular Mobility Unit (EMU). This system provides essential life support--a pure oxygen environment at a differential pressure of 4.2 pounds per square inch, water vapor and carbon dioxide removal, and temperature control while the astronaut is outside the Shuttle (Figure 7). The major components of the EMU are the hard upper torso with the life support systems, lower torso (legs), arms, helmet, and liquid cooling and ventilation garment. Each component comes in several sizes that are custom fitted to astronauts. The EMU, which can be reused during a Shuttle mission, is designed for a 15-year lifetime.

A silver zinc battery provides power for monitoring and controlling the life support systems, circulating fluids, and communicating with Shuttle. The EMU has a $16.5 \mathrm{~V}$ (11 cell) battery rated at $27 \mathrm{Ah}$. Each EMU has a new battery that is filled and charged just before launch. The battery capacity allows continuous operation of the EMU for up to 7 hours and can be recharged in orbit with Shuttle power. A recent series of tests (5) allowed the wet life of these batteries to be extended from 135 to 166 days or about 3 Shuttle missions.

\section{AEROSPACE FLIGHT BATTERY SYSTEMS PROGRAM}

The origin of the NASA Aerospace Flight Battery Systems Program was the Administrator's concern over battery-related launch delays and even the shorting of a battery prior to a launch. NASA formed a Steering Committee in 1985 to review battery requirements for future missions and to investigate ways to increase the safety, reliability, and performance of space power systems. The Steering Committee participated in the development of a program plan for a NASAwide effort with objectives, tasks, a budget, and a schedule.

The program objectives are to enhance cell/battery safety and reliability, maintain current battery technology, increase fundamental understanding of primary and secondary cells, support development of advanced technology for flight use, reduce battery technology related risk, and ensure that safe and reliable batteries are available for NASA's future missions. The technical approach employed in the program establishes technical guidelines for procurement, design, production, testing, and operation; opens and maintains communications lines among NASA field installations and the aerospace battery community; qualifies advanced technologies; and implements independent cell verification. The program recently redefined some tasks in response to continuing problems with the production of $\mathrm{Ni}$-Cd cells.

The program's sponsor is the Engineering Division in the Office of Safety and Mission 
Quality at NASA Headquarters. NASA's Lewis Research Center (LeRC) has overall program management responsibility. Specific projects (Figure 8) are assigned to various NASA field installations. The program has tasks addressing battery systems technology, secondary batteries, primary batteries, and program management. Reference 4 has a general history and overview of this program.

The Battery Systems Technology Task addresses handbooks, training, a data base, and the NASA Battery Workshops. Under this task, Goddard Space Flight Center (GSFC) is preparing a Handbook for Nickel-Hydrogen Batteries and a Handbook for the Handling and Storage of NickelCadmium Batteries that will become the basis for the training effort by Kennedy Space Center (KSC). LeRC is developing the data base that will compile knowledge gained from manufacturing, ground testing, and flight experience. This effort includes a computer bulletin board for problem reporting, technical notes, test reports, and policy documents. The Marshall Space Flight Center (MSFC) conducts the NASA Aerospace Battery Workshop, (see NASA Conference Publications 3119 and 3140).

To provide independent checks and balances, NASA invested in expanded and improved battery test facilities at GSFC, the Jet Propulsion Laboratory (JPL), and the Naval Weapons Support Center in Crane, Indiana. Crane currently places its test data into a computer data base. In addition, LeRC is developing a method for non-destructive evaluation by impedance spectroscopy of secondary cells, and MSFC is establishing procedures for destructive physical analysis.

The Secondary Battery Technology Task includes both $\mathrm{Ni}-\mathrm{Cd}$ and $\mathrm{Ni}-\mathrm{H}_{2}$ battery activities. The Ni-Cd efforts specifically address the cell quality and reliability problems that surfaced in the late 1980's. In the near term, GSFC will convert the existing NASA Ni-Cd specification, Reference 5, into a guidelines document and where necessary strengthen the technical and quality assurance requirements. Gates will manufacture cells with modified plates and separators for a statistically designed experiment that evaluates nickel attack level, positive plate loading, and negative plate loading. GSFC and Crane began testing cells developed by Hughes and SAFT about two years ago. Additional cells from SAFT and Sanyo will enter testing at Crane in 1993.

The far-term solution is advanced Ni-Cd cells with electrochemically impregnated plates and non-nylon separators (similar to the Topex backups and the Hughes cells under test at Crane) or $\mathrm{Ni}-\mathrm{H}_{2}$ cells. LeRC leads the effort for $\mathrm{Ni}-\mathrm{H}_{2}$ evaluation that demonstrated the advantages of a 26 percent $\mathrm{KOH}$ electrolyte concentration and a catalyzed wall wick for aerospace applications. GSFC will prepare a guideline document for $\mathrm{Ni}-\mathrm{H}_{2}$ cells.

JPL leads an effort to develop computer models of the $\mathrm{Ni}-\mathrm{Cd}$ and $\mathrm{Ni}-\mathrm{H}_{2}$ electrochemical systems. The initial Ni-Cd model, available now, uses the table look-up approach to predict battery performance, specifically voltage and efficiency vs. temperature and state-of-charge. Predictions made by the second version, with a one dimensional electrochemical model, generally match test data, although the model needs some modifications and additional verifications. The goal is models that can be used to develop accelerated test methods for determining battery quality
and reliability.

The objective of the Primary Battery Task is improved performance, reliability, and safety, particularly for cells used on Shuttle missions. As the leader for this task, Johnson Space Center (JSC) prepared a Primary Battery Design and Safety Handbook. JSC investigated Yardney's patented thermal short circuit protection method for Lithium K-cells but found the performance 
degradation unacceptably high. Both JSC and JPL obtained promising test results on some $\mathrm{LiSOCl}_{2}$ cells. JSC supported development on two $\mathrm{Zr}-\mathrm{O}_{2}$ cells with capacities of 9-12 and 150$200 \mathrm{Ah}$ that exceeded performance goals for capacity and specific energy at discharge rates of 1 to $6 \mathrm{~A}$.

\section{SUMMARY}

Batteries used in several current space programs are described. NASA's unique requirements for aerospace batteries have necessitated the writing of their own standards and the establishment of a Steering Committee for oversight of the requirements, safety and reliability of these systems.

\section{REFERENCES}

1. GSFC 74-150000, Specification for the Manufacturing of Aero-Space Nickel-Cadmium Storage Cells.

2. NASA 50 Ah Ni-Cd Battery Manual, NASA CR 166701.

3. EMU Ag-Zn Battery Wet-life Extension Test, in The 1991 NASA Aerospace Battery Conference, NASA Conference Publication 3140, 1992, pp. 249-260.

4. Manzo, M. and O'Donnell, P. NASA Flight Battery Program, An Update, in the 1991 NASA Aerospace Battery Conference, NASA Conference Publication 3140, 1992, pp. 7 18.

5. NHB 8073.1, NASA Specification for Manufacturing and Performance Requirements of NASA Standard Aerospace Nickel-Cadmium Cells.

\section{FIGURES}

Fig. 1 Topex/Poseidon Spacecraft

Fig. 2 A $50 \mathrm{Ah} \mathrm{Ni-Cd} \mathrm{cell,} \mathrm{and} \mathrm{two} \mathrm{smaller} \mathrm{cells}$

Fig. 3 Space Shuttle deploys a Tracking and Date Relay Satellite

Fig. 4 Mars Observer spacecraft

Fig. 5 Hubble Space Telescope

Fig. 6 Hubble's Ni-H $\mathrm{H}_{2}$ cells

Fig. 7 Extravehicular Mobility Unit

Fig. 8 NASA Aerospace Battery Program tasks and management 
Table 1. Typical Aerospace Battery Duty Cycles

\begin{tabular}{llcc}
\hline $\begin{array}{l}\text { Aerospace } \\
\text { Application } \\
\text { (orbit) }\end{array}$ & $\begin{array}{c}\text { Minimum } \\
\text { Charge } \\
\text { Time }\end{array}$ & $\begin{array}{c}\text { Maximum } \\
\text { Discharge } \\
\text { Time }\end{array}$ & $\begin{array}{c}\text { Cycles } \\
\text { per } \\
\text { Year }\end{array}$ \\
\hline $\begin{array}{l}\text { Low Earth } \\
\text { Geostationary }\end{array}$ & $\begin{array}{c}60 \mathrm{~min} \\
22 . \mathrm{hr}\end{array}$ & $\begin{array}{c}35 \mathrm{~min} \\
1.3 \mathrm{hr}\end{array}$ & $\begin{array}{c}6000 \\
90\end{array}$ \\
\hline
\end{tabular}



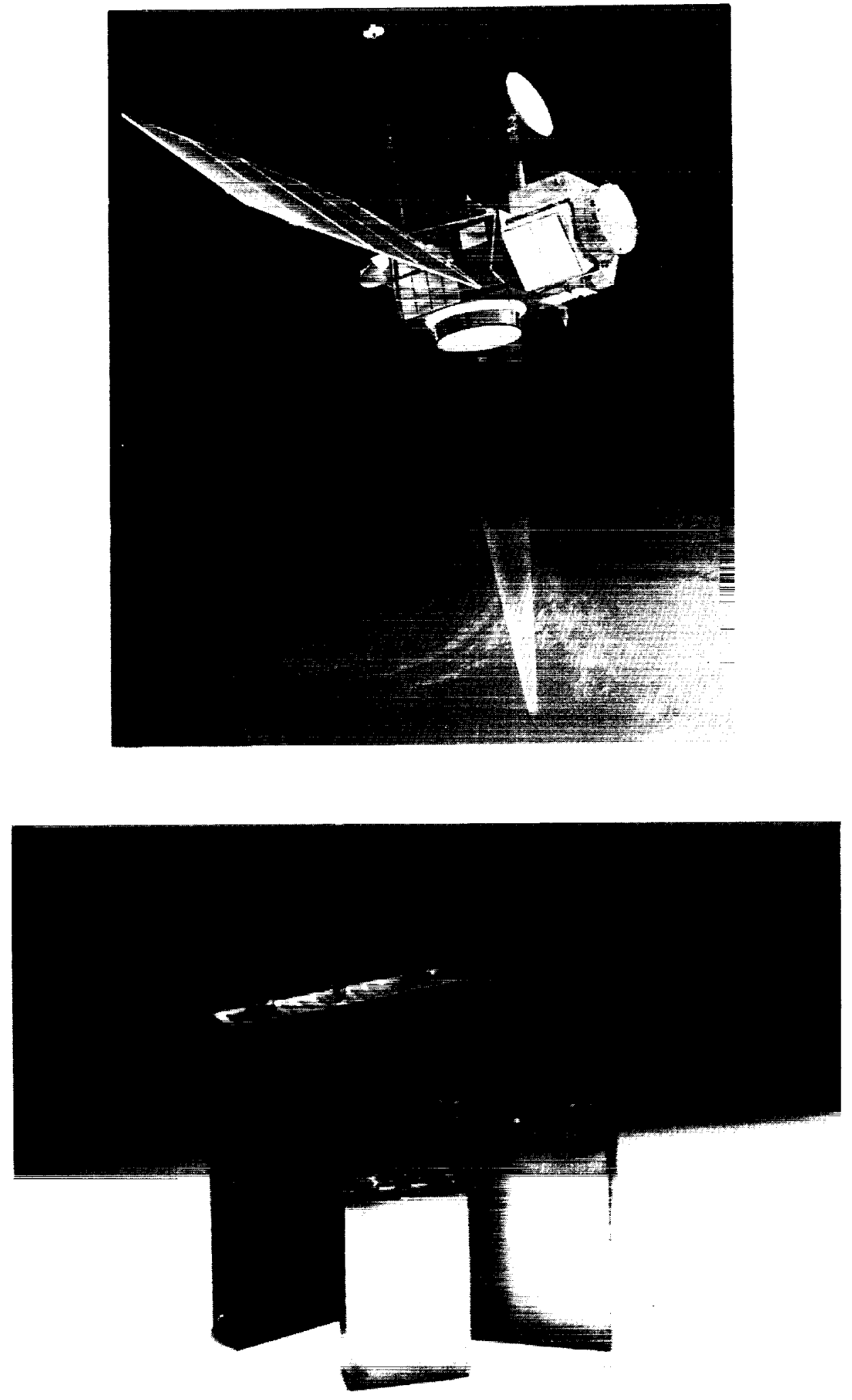

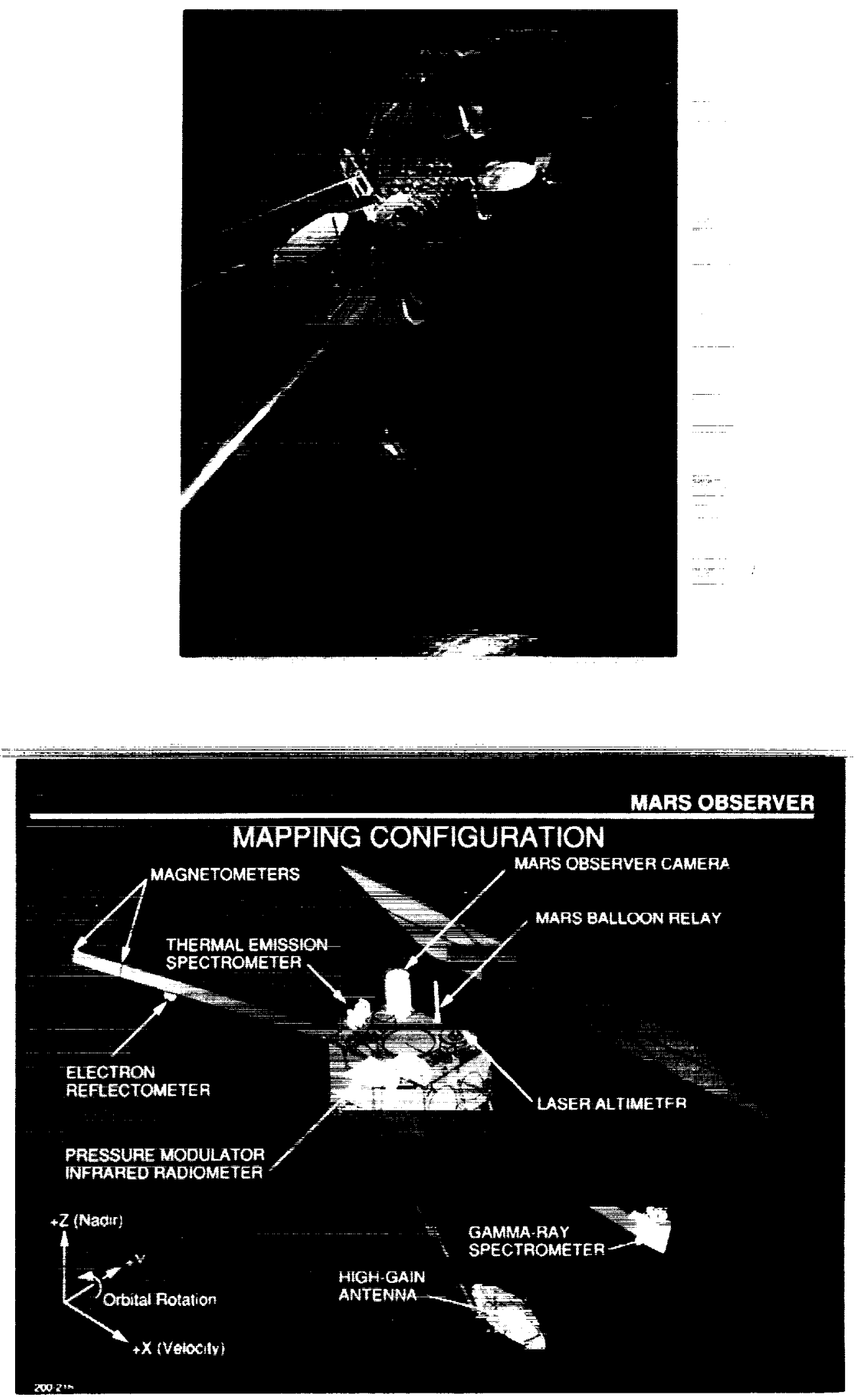

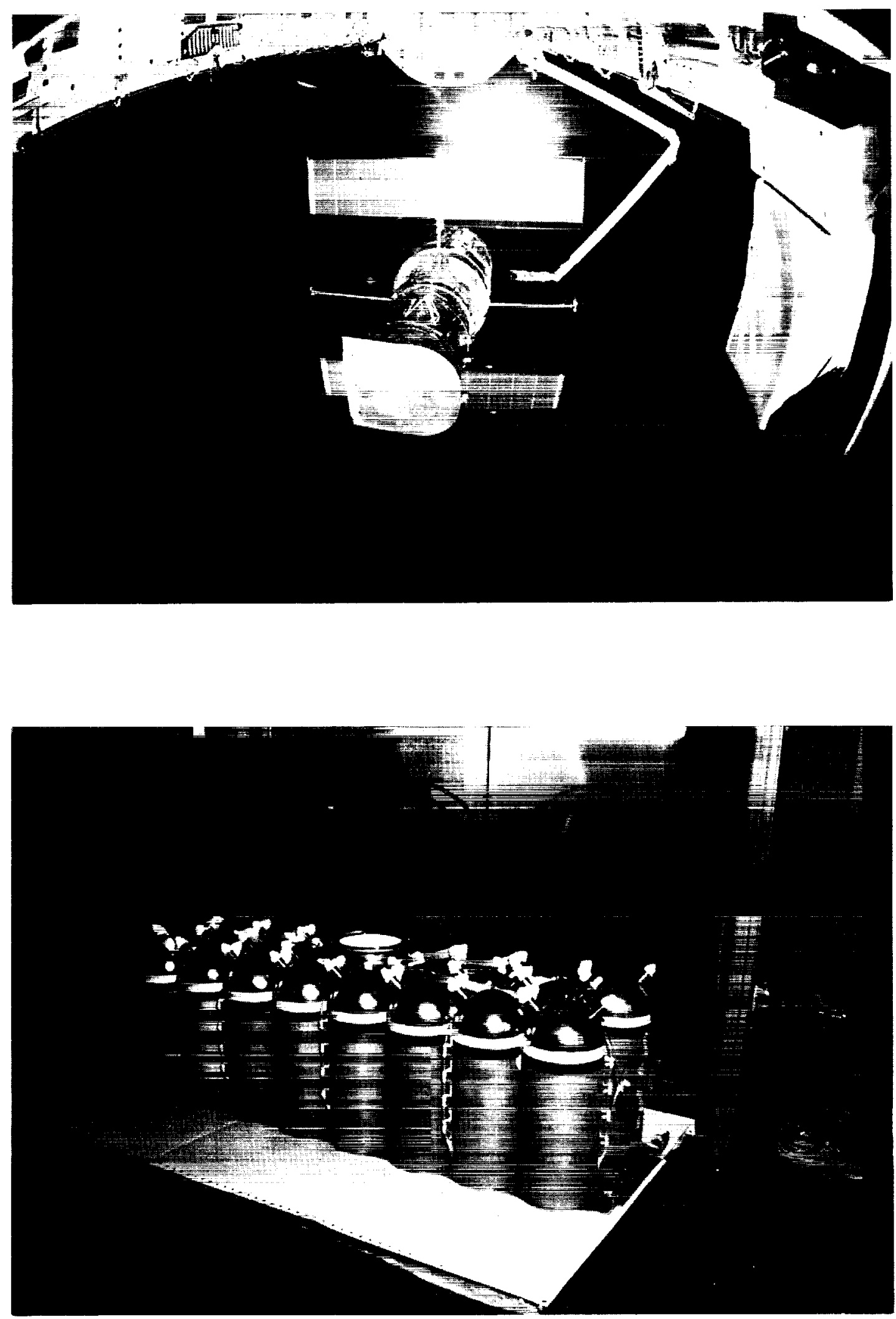

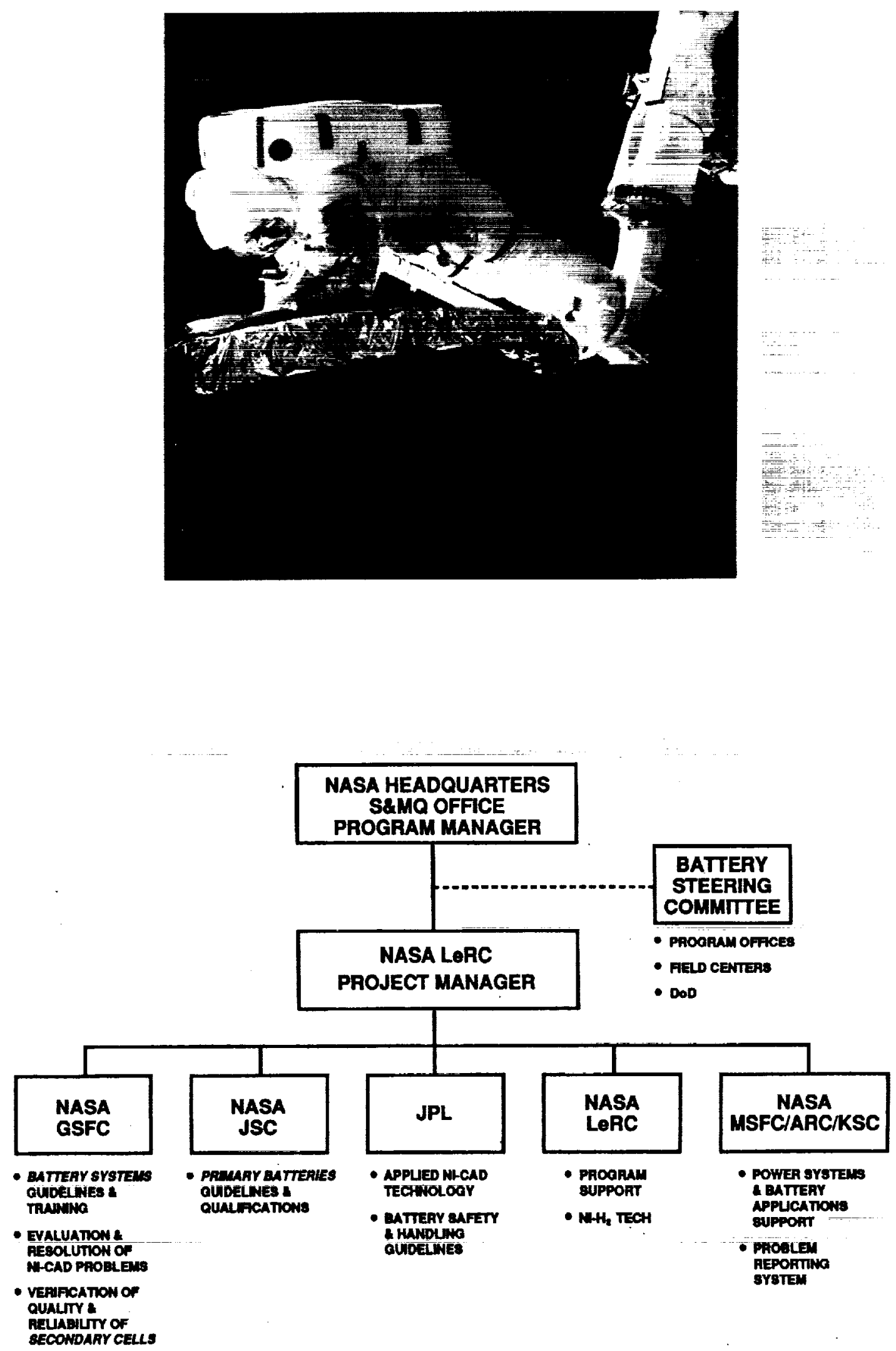